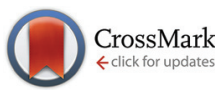

Cite this: Org. Biomol. Chem., 2017, 15, 2163

Received 30th January 2017, Accepted 13th February 2017

DOI: 10.1039/c7ob00235a

rsc.li/obc

\section{Broad scope gold(I)-catalysed polyenyne cyclisations for the formation of up to four carbon-carbon bonds $\uparrow$}

\author{
Zhouting Rong $^{\mathrm{a}}$ and Antonio M. Echavarren*a,b
}

\begin{abstract}
The polycyclisation of polyenynes catalyzed by gold( $(1)$ has been extended for the first time to the simultaneous formation of up to four carbon-carbon bonds, leading to steroid-like molecules with high stereoselectivity in a single step with low catalyst loadings. In addition to terminal alkynes, bromoalkynes can also be used as initiators of polyene cyclisations, giving rise to synthetically useful cyclic bromoalkenes.
\end{abstract}

Gold(I)-catalyzed cycloisomerisations of $1, n$-enynes as well as the reactions of these substrates with many nucleophiles allow the construction of complex carbo- and heterocyclic compounds by the selective activation of the alkyne in the presence of many other functional groups. ${ }^{1}$ These transformations have been used as the key steps in the total synthesis of diverse natural products. ${ }^{2,3}$ In most cases, such as in substrates $\mathbf{1 a},{ }^{4}$ nucleophilic additions to 1,5-enynes proceed by an overall 6endo-dig/endo-trig process leading to the formation of cyclohexenes 2a via a bicyclic gold(I) carbene intermediate. ${ }^{5,6}$ However, hydroxy-1,5-enyne $\mathbf{1 b}$ reacts in the presence of $\mathrm{AuCl}_{3}$ to exclusively form cyclopentene $\mathbf{2 b}$ by a 5-endo-dig/exo-dig cyclisation in which the alcohol adds to the alkene with an anti-Markovnikov regioselectivity (Scheme 1). ${ }^{4}$ Similar transformations have been reported with 1,6-enynes bearing hydroxyl $^{7}$ or carboxylic acid groups at the alkenyl chain. ${ }^{8,9}$

Remarkable examples of gold(I)-catalysed cyclisations in which up to 2-3 carbon-carbon bonds were formed had been reported by Toste, ${ }^{9}$ Michelet, ${ }^{10}$ and by other groups. ${ }^{11}$ Thus, the 6-exo-dig/endo-trig cyclisation of 3 with a chiral gold(I) catalyst leads to tetracyclic compound $\mathbf{4}$ in a highly enantioselective process (Scheme 2). ${ }^{9,12,13}$ Similar intriguing is the 6endo-dig/endo-trig cyclisation of $\mathbf{5}$, which is terminated by trap-

\footnotetext{
${ }^{a}$ Institute of Chemical Research of Catalonia (ICIQ), Barcelona Institute of Science and Technology, Av. Països Catalans 16, 43007 Tarragona, Spain.

E-mail: aechavarren@iciq.es

${ }^{b}$ Departament de QuímicaAnalitica i QuímicaOrgànica, UniversitatRovira i Virgili, C/ Marcel-li Domingo s/n, 43007 Tarragona, Spain

$\dagger$ Electronic supplementary information (ESI) available. CCDC 1530340 and 1530341. For ESI and crystallographic data in CIF or other electronic format see DOI: $10.1039 / \mathrm{c} 7 \mathrm{ob} 00235 \mathrm{a}$
}

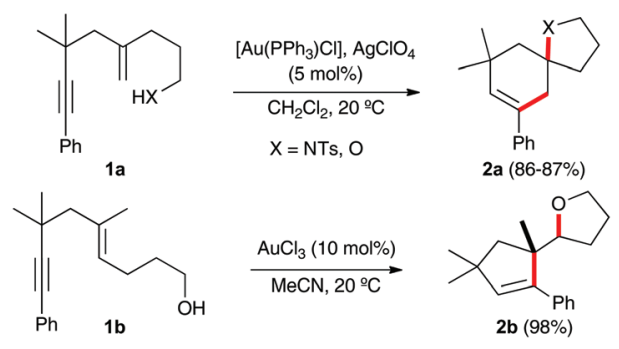

Scheme 1 Gold(I)-catalysed intramolecular heterocyclisation of 1,5enynes $1 \mathbf{a}-\mathbf{b} .^{4}$

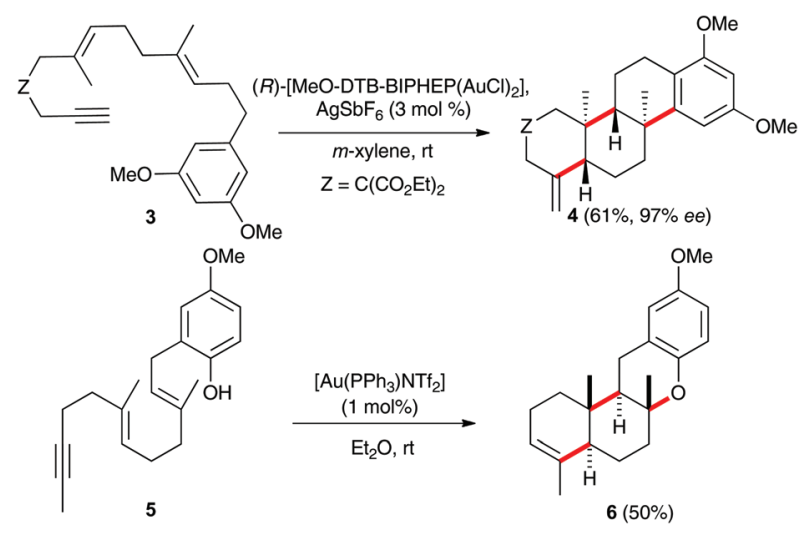

Scheme 2 Gold(I)-catalysed polycyclisations of dienynes 3 and 5 .

ping of the cationic intermediate by the phenol to form $6 .^{10 a}$ Although highly ordered, concerted mechanisms have been proposed for these polycyclisations, ${ }^{8}$ step-wise processes have been suggested for reactions involving external nucleophiles and in other processes. ${ }^{1 j, 3 d, 11 a, 14}$

Recently, the group of Gagné reported the polycyclisation of pentanene 7 with a pincer-platinum(II) catalyst to give steroidlike product 8 (Scheme 3 ). ${ }^{15}$ This fascinating transformation, clearly reminiscent of sterol biosynthesis from squalene in bacteria, ${ }^{16}$ allows the formation of four $\mathrm{C}-\mathrm{C}$ bonds in a single step. $^{17}$ 


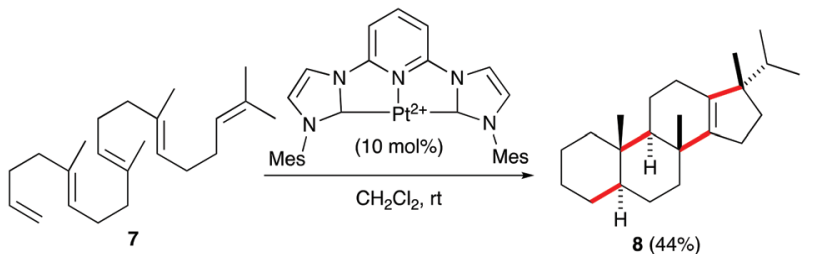

Scheme 3 Platinum(॥)-catalysed polycyclisation of pentanene 7.

We decided to explore the possibility of performing gold(I)catalysed cyclisations analogous to that of pentanene 7 but with a terminal alkyne instead of an alkene to form steroidlike products functionalised with an alkene at the A ring. As a first step towards this goal, we studied a set of 1,5-enynes substituted with different alcohols, phenols, arenes, and heteroarenes as potential nucleophiles. In addition to terminal alkynes, which were not broadly studied previously, ${ }^{10,18}$ we decided to employ 1-bromo-1,5-enynes as the initiators of cyclisation. Surprisingly, bromoalkynes have seldom been used in gold-catalysed cyclisations. ${ }^{19,20}$

At the outset, we examined the cyclisation of $(E)-2,6-$ dimethyldeca-1,5-dien-9-yne (9a) with gold(I) catalysts A-F bearing electronically different bulky groups (Table 1). In all cases, trans-fused hexahydronaphthalene 10a was cleanly obtained as the major product after $1 \mathrm{~h}$ by using just $1 \mathrm{~mol} \%$ catalyst. As we have observed before in other contexts, the best yields were obtained with cationic gold(I) complexes bearing very bulky biphenylphosphine ligands (Buchwald ligands). ${ }^{1 j, 21}$ In this particular instance, cationic dicyclohexylphosphinobiphenyl gold(I) complex C outperforms Johnphos, $t$-BuXphos, and Xphos complexes A, B, and $\mathbf{D}$ (Table 1, entries $1-4)$.

Table 1 Gold(I)-catalysed cyclisation of dienyne $9 a^{a}$

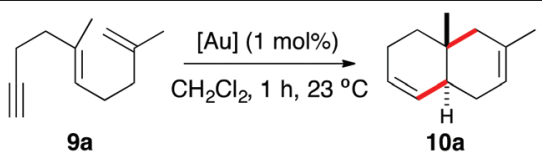

\begin{tabular}{lll}
\hline Entry & Catalyst & Yield $^{b}(\%)$ \\
\hline 1 & A & 84 \\
2 & B & 45 \\
3 & C & 90 \\
4 & D & 41 \\
5 & E & 61 \\
6 & F & 45
\end{tabular}

${ }^{a}$ Reactions carried out with $\mathbf{1 a}(0.3 \mathrm{mmol})$, catalyst $(3 \mu \mathrm{mol})$ in $\mathrm{CH}_{2} \mathrm{Cl}_{2}$ $(3 \mathrm{~mL})$ at $23{ }^{\circ} \mathrm{C}$ for 1 h. ${ }^{b}$ Isolated yields.

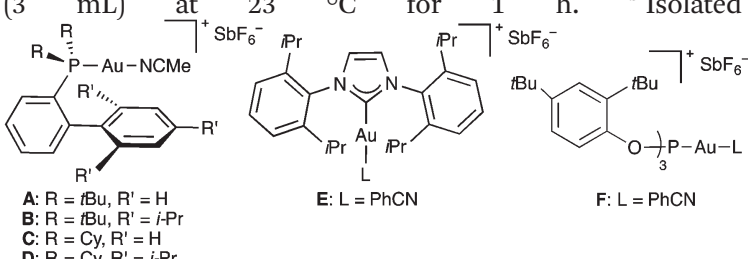

Table 2 Gold(I)-catalysed cyclisation of aryl or heteroaryl 1,5-enynes $9 b-h^{a}$

Entry Substrate<smiles>C#CCCC1=CCOc2cc(OC)cc(OC)c21</smiles>

$9 c$

3<smiles>C#CCCC1=CC[NH2+]c2cc(OC)cc(OC)c21</smiles><smiles>COc1cc(OC)c2c(c1)OCC1C=CCCC21C</smiles>

$54 \%$<smiles>C#CCCC(C)=CCC(CCC#C)(C(C)=O)c1coc2ccccc12</smiles><smiles>COc1cc2c(c(OC)c1)C1(C)CCC=CC1C[NH2+]2</smiles>

$79 \%$

5<smiles>C#CCCC1=CCC(C(=O)OC)(c2cn(C)c3ccc(OC)cc23)C(=O)O1</smiles>

$9 f$

6<smiles>C#CCCC(=C)COCc1cc(OC)cc(OC)c1</smiles><smiles>COC(=O)C1(C(C)=O)Cc2c(oc3ccccc23)C2(C)CCC=C[C@@H]12</smiles>

$80 \%$<smiles>COc1ccc2c(c1)c1c(n2C)C2(C)CCC=C[C@H]2CC1(C)OC</smiles>

$95 \%$

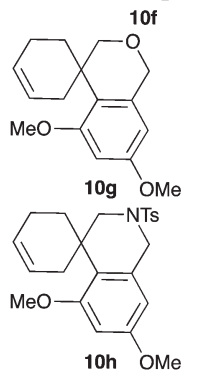

$75 \%$

$98 \%$

${ }^{a}$ Reactions carried out with catalyst $\mathbf{C}(3 \mathrm{~mol} \%)$ in $\mathrm{CH}_{2} \mathrm{Cl}_{2}(0.1 \mathrm{M})$ at $23^{\circ} \mathrm{C}$ for $1 \mathrm{~h} .{ }^{b}$ Isolated yields.

Complex C (3 mol\%) was used as the catalyst in the cyclisation of aryl substituted 1,5-enynes (Table 2). The reaction of substrates $\mathbf{9 b - f}$ bearing electron-rich aromatic and heteroaromatic rings as cyclisation terminators proceeds to give products 10b-f as single diastereomers in good yields in all cases, with the exception of 10c, which was obtained in $54 \%$ yield (Table 2, entries 1-5). Similar results have been obtained with different metal catalysts using 1,5-enynes analogous to $\mathbf{9 b - c}$ with a methyl substituent at the terminal alkyne. ${ }^{10 b, 12 b, 13}$ The trans-relative configuration was confirmed by X-ray diffraction in the case of indole derivative 10f (Fig. 1), which has a carbon skeleton somewhat related to that of the alkaloids aristomakinine and aristomakine, although for these natural products a cis-hexalin structure has been assigned. ${ }^{22}$ The gold(I)catalysed cyclisation of 1,5-enynes $\mathbf{9 g}-\mathbf{h}$ substituted at C-5, gave spirocyclic derivatives $\mathbf{1 0 g}-\mathbf{h}$ in good to excellent yields 

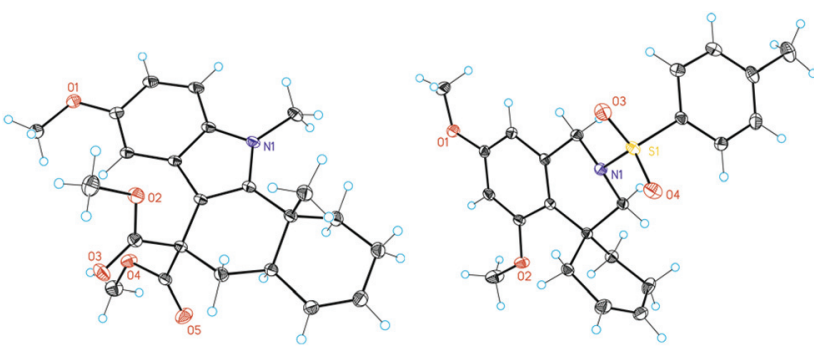

Fig. 1 ORTEP plot (50\% thermal ellipsoids) of the crystal structure of $10 \mathrm{f}$ (left) and 10h (right).

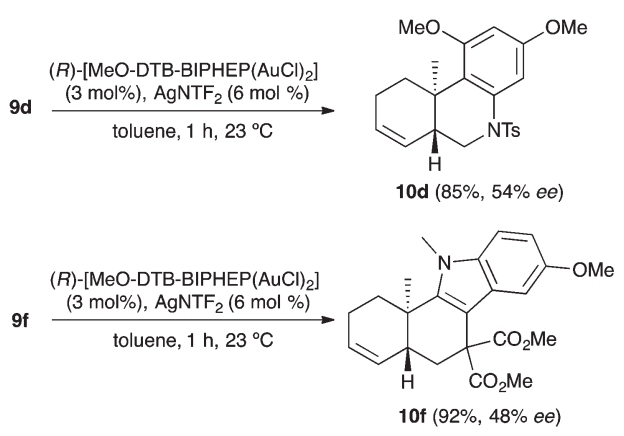

Scheme 4 Gold(I)-catalysed enantioselective cyclisation of $9 \mathrm{~d}$ and $9 \mathrm{f}$

(Table 2, entries 6 and 7). The structure of $\mathbf{1 0 h}$ was confirmed by X-ray diffraction (Fig. 1).

We also tested several chiral gold(I) catalysts in the cyclisation of enynes 9d and $\mathbf{9 f} .^{23,24}$ However, despite the excellent cyclisation yields, the enantioselectivities achieved with the dinuclear gold(I) complex of [MeO-DTB-BIPHEP] in the presence of $\mathrm{AgNTf}_{2}$ were only moderate (54 and $48 \%$ ee, respectively) (Scheme 4). ${ }^{25}$

The intramolecular addition of alcohols and phenols was briefly studied with substrates $\mathbf{9 i - k}$ (Table 3 ). As expected considering the precedents, ${ }^{10}$ products $\mathbf{1 0} \mathbf{i}-\mathbf{k}$ were obtained in good to excellent yields. Spirocyclisations similar to that of $\mathbf{9 i}$ to form 10i could be applied for the synthesis of analogues of the natural product filifolinol and other more complex, biologically active compounds with a spirobenzofuran structure. ${ }^{26}$

The cyclisation of 1-bromo-1,5-enynes 91-n and 1-bromo1,5,9-dienyne $\mathbf{9 o}$ with catalyst $\mathbf{C}$ took place uneventfully under the usual reaction conditions to give products 10l-o in good yields (Table 4). These results show that bromoalkynes are perfectly suitable initiators of gold(I)-catalysed polycyclisations. The final products are bromoalkenes, which could be further functionalized by metal-catalysed cross-couplings, carbonylations, or by other methods.

The polycyclisation of trienynes $\mathbf{9 p - q}$ and tetraenynes $\mathbf{9 r}-\mathbf{s}$ was similarly performed with catalyst $\mathbf{C}(1-3 \mathrm{~mol} \%)$ to give triand tetracyclic compounds 10p-s (Table 5). Considering that four $\mathrm{C}-\mathrm{C}$ bonds are formed in a single step, the catalytic transformations of tetraenynes $\mathbf{9 r}-\mathbf{s}$ into 10r-s are quite remarkable and comparable to that achieved by Gagné in the Pt(II)-cata-
Table 3 Gold(I)-catalysed cyclisation hydroxyl-cyclisation of $\mathbf{9 i - \mathbf { k } ^ { a }}$

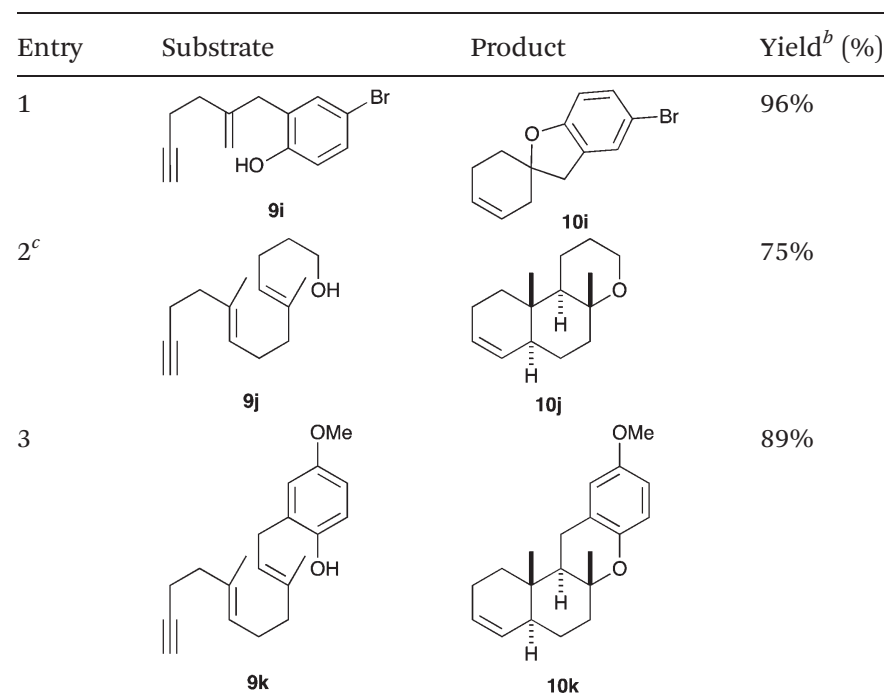

${ }^{a}$ Reactions carried out with catalyst $\mathbf{C}(3 \mathrm{~mol} \%)$ in $\mathrm{CH}_{2} \mathrm{Cl}_{2}(0.1 \mathrm{M})$ at $23{ }^{\circ} \mathrm{C}$ for $1 \mathrm{~h} .{ }^{b}$ Isolated yields. ${ }^{c} 1 \mathrm{~mol} \%$ catalyst $\mathbf{C}$.

Table 4 Gold(I)-catalysed cyclisation of 1-bromo-1,5-enynes 9l-o

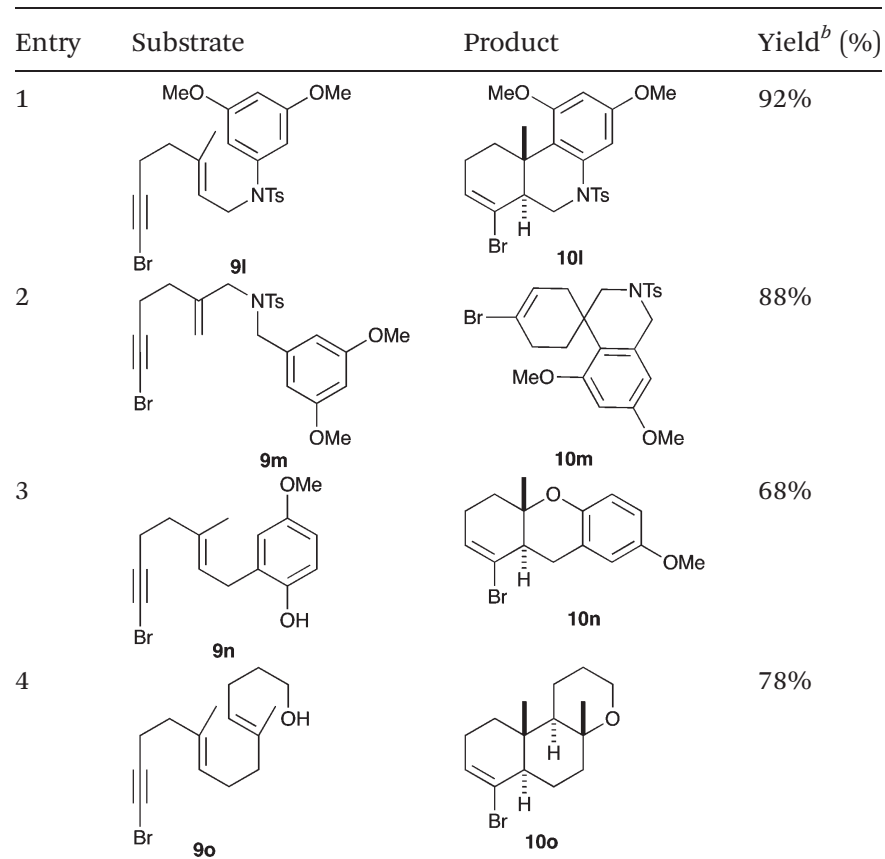

${ }^{a}$ Reactions carried out with catalyst $\mathbf{C}(3 \mathrm{~mol} \%)$ in $\mathrm{CH}_{2} \mathrm{Cl}_{2}(0.1 \mathrm{M})$ at $23{ }^{\circ} \mathrm{C}$ for $1 \mathrm{~h} .{ }^{b}$ Isolated yields.

lysed polycyclisation of pentanene 7 (Scheme 3). ${ }^{15,27}$ However, in our case a lower catalyst loading is required and the final tetracyclic derivatives 10r-s feature two differently substituted double bonds. In 10s, the alkenyl bromide offers a handle for further functionalisation of the A-ring.

Presumably, the cyclisation of $9 \mathrm{~s}$ to give 10 s proceeds by the initial formation of gold(I)-carbene intermediate ${ }^{5,11}$ which trig- 
Table 5 Gold(I)-catalysed cyclisation of tri- and tetraenynes $9 p-s^{a}$

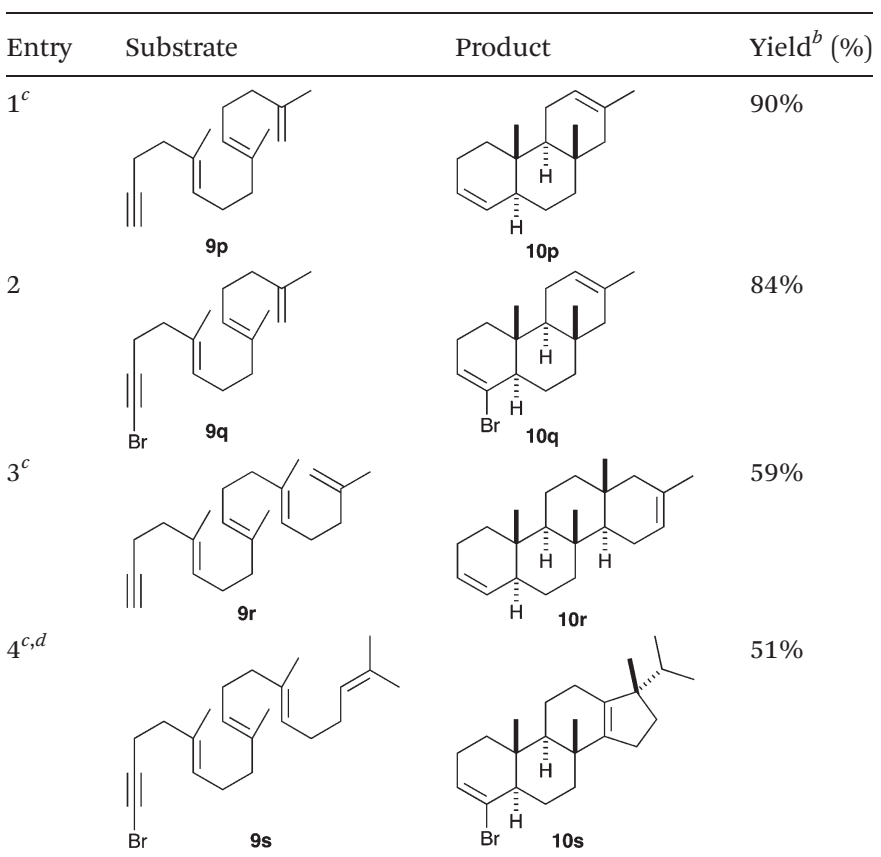

${ }^{a}$ Reactions carried out with catalyst $\mathbf{C}(3 \mathrm{~mol} \%)$ in $\mathrm{CH}_{2} \mathrm{Cl}_{2}(0.1 \mathrm{M})$ at $23{ }^{\circ} \mathrm{C}$ for 1 h. ${ }^{b}$ Isolated yields. ${ }^{c} 1$ mol\% catalyst $\mathbf{C} .{ }^{d}$ Reaction at $0{ }^{\circ} \mathbf{C}$.

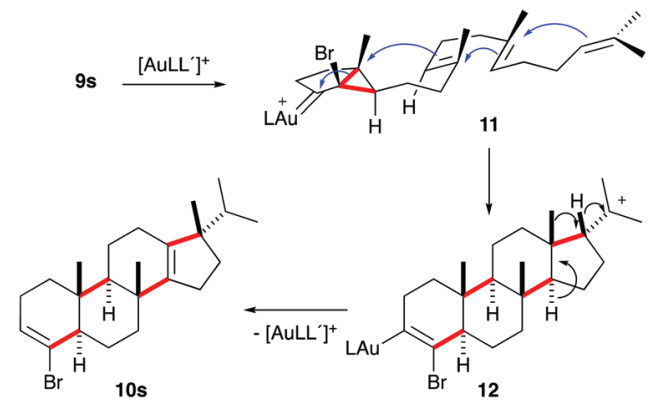

Scheme 5 Mechanism for the formation of 10s.

gers a cascade process to form secondary carbocation 12 (Scheme 5). The final tetracyclic compound 10s is then formed by Wagner-Meerwein 1,2 $\mathrm{H}$ and Me migrations, ${ }^{15,28}$ followed by the proton elimination and protonolysis of the alkenyl-gold(I) bond.

In summary, building upon previous studies, ${ }^{9,10}$ we have extended the polycyclisation of polyenynes up to the simultaneous formation of four $\mathrm{C}-\mathrm{C}$ bonds. These reactions are performed under mild conditions with low catalyst loadings (1-3 mol\%) of a cationic dicyclohexylphosphinobiphenyl gold(I)complex with a weakly coordinating acetonitrile ligand. In addition to terminal alkynes, we have also found that bromoalkynes can be used as the initiators of polyene cyclisations, leading to synthetically useful cyclic bromoalkenes. Further work on the development of broad scope and practical solutions of the asymmetric polycyclisation of polyeneynes is underway.

\section{Acknowledgements}

We acknowledge funding from MINECO/FEDER, UE (CTQ2016-75960-P), MINECO-Severo Ochoa Excellence Accreditation 2014-2018, (SEV-2013-0319), the European Research Council (Advanced Grant No. 321066), the AGAUR (2014 SGR 818), and CERCA Programme/Generalitat de Catalunya. We also thank the ICIQ X-ray diffraction unit and CELLEX-ICIQ HTE laboratory.

\section{References}

1 Selected reviews: (a) L. Zhang, J. Sun and S. A. Kozmin, Adv. Synth. Catal., 2006, 348, 2271-2296; (b) A. Fürstner and P. W. Davies, Angew. Chem., Int. Ed., 2007, 46, 34103449; (c) A. S. K. Hashmi, Chem. Rev., 2007, 107, 31803211; (d) E. Jiménez-Núñez and A. M. Echavarren, Chem. Rev., 2008, 108, 3326-3350; (e) D. J. Gorin, B. D. Sherry and F. D. Toste, Chem. Rev., 2008, 108, 3351-3378; (f) V. Michelet, P. Y. Toullec and J.-P. Genêt, Angew. Chem., Int. Ed., 2008, 47, 4268-4315; $(g)$ A. Fürstner, Chem. Soc. Rev., 2009, 38, 3208-3221; (h) C. Aubert, L. Fensterbank, P. Garcia, M. Malacria and A. Simonneau, Chem. Rev., 2011, 111, 1954-1993; (i) N. Krause and C. Winter, Chem. Rev., 2011, 111, 1994-2009; (j) C. Obradors and A. M. Echavarren, Acc. Chem. Res., 2014, 47, 902-912; (k) L. Fensterbank and M. Malacria, Acc. Chem. Res., 2014, 47, 953-965; (l) R. Dorel and A. M. Echavarren, Chem. Rev., 2015, 115, 9028-9072.

2 Selected reviews: (a) A. S. K. Hashmi and M. Rudolph, Chem. Soc. Rev., 2008, 37, 1766-1775; (b) M. Rudolph and A. S. K. Hashmi, Chem. Soc. Rev., 2012, 41, 2448-2462; (c) A. Fürstner, Acc. Chem. Res., 2014, 47, 925-938; (d) Y. Zhang, T. Luo and Z. Yang, Nat. Prod. Rep., 2014, 31, 489-503.

3 Work towards the synthesis of natural products by using gold catalysis from our group: (a) E. Jiménez-Núñez, K. Molawi and A. M. Echavarren, Chem. Commun., 2009, 7327-7329; (b) K. Molawi, N. Delpont and A. M. Echavarren, Angew. Chem., Int. Ed., 2010, 49, 35173519; (c) M. Gaydou, R. E. Miller, N. Delpont, J. Ceccon and A. M. Echavarren, Angew. Chem., Int. Ed., 2013, 52, 63966399; (d) J. Carreras, M. Livendahl, P. R. McGonigal and A. M. Echavarren, Angew. Chem., Int. Ed., 2014, 53, 48964899; (e) A. Homs, M. E. Muratore and A. M. Echavarren, Org. Lett., 2015, 17, 461-463; ( $f$ ) B. Ranieri, C. Obradors, M. Mato and A. M. Echavarren, Org. Lett., 2016, 18, 1614-1617; $(g)$ M. S. Kirillova, M. E. Muratore, R. Dorel and A. M. Echavarren, J. Am. Chem. Soc., 2016, 138, 36713674; (h) J. Carreras, M. S. Kirillova and A. M. Echavarren, Angew. Chem., Int. Ed., 2016, 55, 7121-7125; (i) R. Dorel and A. M. Echavarren, J. Org. Chem., 2016, 81, 84448454.

4 L. Zhang and S. A. Kozmin, J. Am. Chem. Soc., 2005, 127, 6962-6963. 
5 M. R. Luzung, J. P. Markham and F. D. Toste, J. Am. Chem. Soc., 2004, 126, 10858-10859.

6 V. López-Carrillo, N. Huguet, Á. Mosquera, A. M. Echavarren and A. M, Chem. - Eur. J., 2011, 17, 10972-10978.

7 C. Nieto-Oberhuber, M. P. Muñoz, S. López, E. JiménezNúñez, C. Nevado, E. Herrero-Gómez, M. Raducan and A. M. Echavarren, Chem. - Eur. J., 2006, 12, 1677-1693. Corrigendum: Chem. - Eur. J., 2008, 14, 5096.

8 A. Fürstner and L. Morency, Angew. Chem., Int. Ed., 2008, 47, 5030-5033.

9 S. G. Sethofer, T. Mayer and F. D. Toste, J. Am. Chem. Soc., 2010, 132, 8276-8277.

10 (a) P. Y. Toullec, T. Blarre and V. Michelet, Org. Lett., 2009, 11, 2888-2891; (b) A. Pradal, Q. Chen, P. F. dit Bel, P. Y. Toullec and V. Michelet, Synlett, 2012, 74-79.

11 (a) S. Böhringer and F. Gagosz, Adv. Synth. Catal., 2008, 350, 2617-2630; (b) A. Buzas, F. Istrate, X. F. Le Goff, Y. Odabachian and F. Gagosz, J. Organomet. Chem., 2009, 694, 515-519; (c) Y. Lee, C. Lim, S. Kim and S. Shin, Bull. Korean Chem. Soc., 2010, 31, 670-677; (d) P.-J. Cai, Y. Wang, C.-H. Liu and Z.-X. Yu, Org. Lett., 2014, 16, 5898-5901; (e) A. Danda, K. Kumar and H. Waldmann, Chem. Commun., 2015, 51, 7536-7539; $(f)$ R. Wildermuth, K. Speck and T. Magauer, Synthesis, 2016, 1814-1824.

12 Related indium(III)-catalysed cyclisations: (a) K. Surendra, W. Qiu and E. J. Corey, J. Am. Chem. Soc., 2011, 133, 97249726; (b) W.-W. Qiu, K. Surendra, L. Yin and E. J. Corey, Org. Lett., 2011, 13, 5893-5895; (c) K. Surendra and E. J. Corey, J. Am. Chem. Soc., 2014, 136, 10918-10920.

13 Related mercury(II)-catalysed cyclisations: H. Imagawa, T. Iyenaga and M. Nishizawa, Org. Lett., 2005, 7, 451-453.

14 (a) N. Huguet and A. M. Echavarren, Synlett, 2012, 49-53; (b) P. Calleja, M. E. Muratore, T. Jiménez and A. M. Echavarren, Synthesis, 2016, 3183-3198; (c) P. Calleja, Ó. Pablo, B. Ranieri, M. Gaydou, A. Pitaval, M. Moreno, M. Raducan and A. M. Echavarren, Chem. - Eur. J., 2016, 22, 13613-13618.

15 (a) M. J. Geier and M. R. Gagné, J. Am. Chem. Soc., 2014, 136, 3032-3035; (b) R. J. Felix, C. Munro-Leighton and M. R. Gagné, Acc. Chem. Res., 2014, 47, 2319-2331.

16 (a) R. A. Yoder and J. N. Johnston, Chem. Rev., 2005, 105, 4730-4756; (b) D. J. Tantillo, Chem. Soc. Rev., 2010, 39, 2847-2854; (c) Y. Gao, R. B. Honzatko and R. J. Petters, Nat. Prod. Rep., 2012, 29, 1153-1175.

17 Recent leading references on enantioselective polyene cyclizations: (a) C. N. Ungarean, E. H. Southgate and D. Sarlah, Org. Biomol. Chem., 2016, 14, 5454-5467; (b) R. C. Samanta and H. Yamamoto, J. Am. Chem. Soc., 2017, 139, 1460-1463.

18 Only two of the substrates reported ref. $10 a$ and $b$ that underwent cyclisation were terminal alkynes.
19 (a) T. Matsuda, S. Kadowaki, Y. Yamaguchi and M. Murakami, Chem. Commun., 2008, 2744-2746; (b) F. Barabé, G. Bétournay, G. Bellavance and L. Barriault, Org. Lett., 2009, 11, 4236-4238; (c) K. Speck, K. Karaghiosoff and T. Magauer, Org. Lett., 2015, 17, 19821985; (d) Intramolecular hydroarylation of bromoalkynes: V. Mamane, P. Hannen and A. Fürstner, Chem. - Eur. J., 2004, 10, 4556-4575.

20 Cyclisation of a 1-bromo-1,5-enyne promoted by $N$-iodosuccinimide: B. Crone, S. F. Kirsch and K.-D. Umland, Angew. Chem., Int. Ed., 2010, 49, 4661-4664.

21 (a) B. Ranieri, I. Escofet and A. M. Echavarren, Org. Biomol. Chem., 2015, 13, 7103-7118; (b) R. Miller, J. Carreras, M. E. Muratore, M. Gaydou, F. Camponovo and A. M. Echavarren, J. Org. Chem., 2016, 81, 1839-1849.

22 S. Burkard and H.-J. Borsehberg, Helv. Chim. Acta, 1990, 73, 298-302.

23 Recent reviews on enantioselective gold(I)-catalysed reactions: (a) S. Sengupta and X. Shi, ChemCatChem, 2010, 2, 609-619; (b) A. Pradal, P. Y. Toullec and V. Michelet, Synthesis, 2011, 1501-1514; (c) W. Zi and F. D. Toste, Chem. Soc. Rev., 2016, 45, 4567-4589; (d) Y. Li, W. Li and J. Zhang, Chem. - Eur. J., 2017, 23, 467-512.

24 Recent lead references on enantioselective gold(I)-catalysed reactions: (a) N. Delpont, I. Escofet, P. Pérez-Galán, D. Spiegl, M. Raducan, C. Bour, R. Sinisi and A. M. Echavarren, Catal. Sci. Technol., 2013, 3, 3007-3012; (b) P. Aillard, D. Dova, V. Magné, P. Retailleau, S. Cauteruccio, E. Licandro, A. Voituriez and A. Marinetti, Chem. Commun., 2016, 52, 10984-10987; (c) Z. Wu, K. Isaac, P. Retailleau, J.-F. Betzer, A. Voituriez and A. Marinetti, Chem. - Eur. J., 2016, 22, 3278-3281; (d) E. GonzálezFernández, L. D. M. Nicholls, L. D. Schaaf, C. Farès, C. W. Lehmann and M. Alcarazo, J. Am. Chem. Soc., 2017, 139, 1428-1431.

25 The absolute configurations of the major enantiomer of 10d and 10f were tentatively assigned following that reported by Toste in the cyclization of substrate 3 with the same dinuclear gold(I) precatalyst. ${ }^{8}$.

26 (a) B. J. Bradbury, P. Bartyzel, T. S. Kaufman, M. J. Nieto, R. D. Sindelar, S. M. Scesney, B. R. Gaumond and H. C. Marsh, J. Med. Chem., 2003, 46, 2697-2705; (b) E. L. Larghi, M. A. Operto, R. Torres and T. S. Kaufman, Eur. J. Med. Chem., 2012, 55, 74-84.

27 Cu-Mediated oxidation in Pt(II)-catalysed cyclisations lead to alcohols and ketones: M. J. Geier and M. R. Gagné, Organometallics, 2013, 32, 380-383.

28 J. G. Sokol, C. S. Korapala, P. S. White, J. J. Becker and M. R. Gagné, Angew. Chem., Int. Ed., 2011, 50, 56585661. 